\title{
NON SPECIFIC RESISTANCE AGAINST MALARIA PRE-ERYTHROCYTIC STAGES : INVOLVEMENT OF ACUTE PHASE PROTEINS
}

\author{
PIED S.*, TABONE M.-D.*, CHATELLIER G.**, MARUSSIG M.*, JARDEL C.***, NOSTEN F.*** \& MAZIER D.*
}

\begin{abstract}
Summary :
Levels of different acute phase proteins were compared in sera from parasitaemic and non-parasitaemic women living in a Plasmodium falciparum endemic area of Thailand. The ability of their sera to interfere with hepatic stage development of the parasite was examined. Correlations were found between levels of $\alpha-$ 1 antitrypsin, $\alpha-2$ macroglobulin, hemopexin and the potential of sera to block hepatocyte invasion by the sporozoite.
\end{abstract}

KEY WORDS : malaria. exo-erythrocytic stage. acute phase proteins. MOTS CLÉS : paludisme. stade exo-erythrocyłaire. protéines de l'inflammation. Abbreviation: APPs : acute phase proteins.

\section{INTRODUCTION}

M alaria infection is contracted after an injection of sporozoites during a mosquito blood meal. The sporozoites invade hepatocytes in which they differentiate, multiply and release merozoites capable of initiating a blood-stage infection. Different mechanisms, involving both specific and non-specific components of the host response against infection, contribute to control malaria parasite development in the liver (Mazier et al., 1990; Rénia et al., 1991; Schofield et al., 1988; Schofield et al., 1989; Weiss et al., 1988; Weiss et al., 1990). Experimentally, there is evidence that acute phase proteins synthetized by the hepatocyte in response to cytokine stimulation also protect hepatocyte against sporozoite infection (Mellouk et al., 1987; Nussler et

* INSERM U 313, Groupe Pitié-Salpêtrière, 91 Bd de l'Hôpital, 75013 Paris, France.

** Service d'informatique médicale, Groupe Pitié-Salpêtrière, 91 bd de l'Hôpital, F-75013 Paris.

*** Laboratoire central de biochimie, Groupe Pitié-Salpêtrière, 47 Bd de l'Hôpital, F-75013 Paris.

**** Faculty of tropical medicine, Mahidol University, Bangkok 1400 , Thailand.

Correspondence : Sylviane Pied, INSERM U 313, CHU PitiéSalpêtrière, 91 Bd de l'Hôpital 75013 Paris, France. Tél. (1) 407797 36 - Fax (1) 45838858.
Résumé : MÉCANISMES NON SPÉCIFIQUES IMPLIQUÉS DANS LA PROTECTION CONTRE LES STADES HÉPATIQUES DU PALUDISME : RÔLE DES PROTÉINES DE LA PHASE AIGUË

Différents mécanismes faisant intervenir à la fois les composants de la réponse immune spécifique et non spécifique de l'hôte contrôlent le développement du plasmodium dans la cellule hépatique. Parmi ces mécanismes interviennent des médiateurs effecteurs tels que l'interleukine-1, l'interleukine-6, l'interféron- $\gamma$ et le facteur de nécrose tumorale qui interfèrent avec la phase pré-érythrocytaire en partie par le biais des protéines de l'inflammation. Cette étude a consisté à comparer l'effet in vitro sur les stades hépatiques des plasmodies, de sérums provenant de deux groupes de femmes vivant en zone endémique dans un camp de réfugiés en Thailande, un groupe ne présentant pas de parasitémie et l'autre étant infecté. Une corrélation a été mise en évidence entre les taux sériques d'alpha-1 antitrypsine, d'alpha-2 macroglobuline, d'hémopexine et le pouvoir inhibiteur des sérums sur le développement hépatique de Plasmodium yoelii.

al., 1991a, 1991b; Pied et al., 1989, 1990). APPs are plasma proteins whose concentrations vary during an inflammatory reaction. The common denominator of this group of proteins is their participation in the non-specific response of the host to tissue damage or infection. C-reactive protein, a major APP in humans, was found to inhibit the pre-erythrocytic stage of Plasmodium yoelii (Pied et al., 1989). Other APPs seem to be involved in inhibitory effects on parasite maturation (Nussler et al., 1991a). The extent to which acute phase reactants participate in resistance to plasmodial infection in humans exposed to natural infection has been studied. Serum levels of APPs from women living in an endemic area in Thailand and with either patent or non-patent infections were compared, and the ability of their sera to inhibit preerythrocytic schizogony was investigated.

\section{MATERIALS AND METHODS}

\section{SUBJECTS}

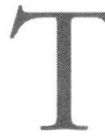
he people studied were amongst the Karen refugee population of Thailand. This population was selected because of their high rate of exposure to malaria in comparison with other ethnic groups of Thailand. Nineteen women with a mean 
age of 25.5 years (range 16-45) participated in the study. All of these women lived under the same conditions in a refugee camp and gave their informed consent to participate as controls in a pharmacological study on the efficacy of mefloquine in prophylaxis. Blood samples were taken every fifteen days and percentage of parasitemia was determined. They formed two groups : nine women who exhibited $P$. falciparum during the period of examination constituted the patent parasitemia group. None of these women had any demonstrable organ involvement as a result of the infection and were considered to have uncomplicated malaria which was treated effectively with quinine $(30 \mathrm{mg} / \mathrm{kg} / \mathrm{d}$ for 7 days). Ten other women who never exhibited any $P$. falciparum parasites in thick blood smears during the period of the study formed the non-patent group.

\section{QUANTITATION OF ACUTE PHASE PROTEINS}

C-reactive protein, $\alpha-2$ macroglobulin, $\alpha-1$ antitrypsin, $\alpha-1$ glycoprotein acid, C3, C4, hemopexin, ceruloplasmin, haptoglobin, fibronectin, transferrin, albumin and pre-albumin levels were measured in the serum samples by automatic Behring laser nephelometry. Proteins were detected on the basis of changes in light-scattering properties due to formation of soluble immune complexes following the addition of specific antibody (Behring, France). After thawing, lipid was removed from the sera before quantification.

\section{PARASITES}

Sporozoites of the NF54 strain of $P$. falciparum were obtained from Anopheles stephensi after membrane feeding on cultures of blood containing gametocytes. Sporozoites of the 265 BY strain of $P$. yoelii yoelii were extracted from infected salivary glands of $A$. stephensi mosquitoes, 16 to 21 days after an infective blood meal. After aseptic dissection, salivary glands were homogenized in a glass grinder and diluted in culture medium.

\section{TITRATION}

Sera were titrated for specific antibodies directed against $P$. falciparum and $P$. yoelii sporozoites using an IFAT performed with a dried preparation of parasites (Mazier et al., 1986).

\section{Culture OF HEPATIC STAGE (Mazier et al., 1985)}

$\mathrm{Balb} / \mathrm{c}$ mouse hepatocytes were isolated by collagenase perfusion of liver fragments. Briefly, after dissociation, $10^{5}$ hepatic cells were seeded into eight-chamber plastic Labtek slides (Miles laboratory, Inc, Elkhard, IN, USA) in supplemented Minimum Essential Medium (MEM) and incubated with $5 \% \mathrm{CO}_{2}$ at $37^{\circ} \mathrm{C}$ for 24 hours before experiments. Cultures were inoculated with 40,000 P. yoelii sporozoites and examined 48 hours later. Scinizonts were detected by an IFAT using antisera recognizing the hepatic stage of $P$. yoelii. Percentage inhibition of parasite development was calculated by comparing the number of parasites in experimental cultures with those in control cultures.

\section{Culture TREatment}

Each serum tested was used after removal of immunoglobulins by affinity chromatography using protein A sepharose. Hepatocyte cultures were treated with patient's sera or purified $\alpha-1$ antitrypsin, $\alpha-2$ macroglobulin (Sigma, France) and hemopexin (kindly given by Dr. U. Müller-Eberhard, Cornell University Medical College, New York) at the time of sporozoite inoculation. Neutralization experiments were performed by adding anti- $\alpha-1$ antitrypsin, anti- $\alpha-2$ macro-

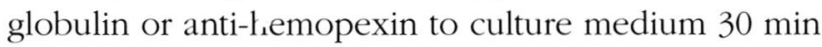
before cell treatment and inoculation.

\section{STATISTICAL METHODS}

Three to five blood samples were obtained from each woman every two to four weeks. The means of the measurements obtained during the period were determined and statistical analyses made on these mean values. The comparison of two means was performed with the non-parametric Mann-Whitney U test (comparison between groups). The relationship between two variables was tested with the Pearson correlation coefficient. Linear regression was done by the least squares method. All the calculations were done with the Statview Software. Data are means $(+/-S D)$. A p value less than 0.05 was considered significant.

\section{RESULTS}

Serum LeVels OF APPs.

lycoprotein serum levels were determined for the patent and non-patent groups (Table I). Comparisons of the mean levels of the different plasma proteins in sera of women without demonstrable parasitaemia with women who became parasiteamic during the course of the study showed no significant differences except increased level of $\alpha$ 1 antitrypsin, $\alpha-2$ macroglobulin, hemopexin and low quantities of haptoglobin in the patent group.

\section{ANTIBODY TITERS.}

Antibody titers against $P$. falciparum and $P$. yoelii sporozoites were determined for all samples ( $P$. falciparum titer : $1 / 7200+/-179$ and $P$. yoelii titer : $1 / 690$ $+/-75)$. No correlation was found between antibody 


\begin{tabular}{lcc}
\hline & Non-patent & Patent \\
\hline C3 & $1.14+/-0.16$ & $1.22+/-0.14$ \\
C4 & $0.38+/-0.16$ & $0.30+/-0.13$ \\
Transferrin & $4.08+/-0.97$ & $3,93+/-0.67$ \\
Albumin & $32.8+/-3.02$ & $31.0+/-7.04$ \\
Pre-Albumin & $0.23+/-0.05$ & $0.24+/-0.04$ \\
Haptoglobin & $1,84+/-0.51$ & $0.64+/-0.49$ \\
$\alpha-1$ Acid Glycoprotein & $0.49+/-0.23$ & $0.52+/-0.20$ \\
$\alpha-1$ Antitrypsin & $2,73+/-0.85$ & $4.62+/-0.50$ \\
Ceruloplasmin & $0.72+/-0.12$ & $0.75+/-0.10$ \\
Retinol-Binding-Protein & $37.6+/-9.55$ & $38.7+/-10.6$ \\
Fibronectin & $0.20+/-0.08$ & $0.18+/-0.07$ \\
C-Réactive Protein & $3.08+/-4.78$ & $3.61+/-3.79$ \\
$\alpha-2$ Macroglobulin & $2.99+/-0.73$ & $3.99+/-0.63$ \\
Hemopexin & $0,8+/-0.17$ & $1.01+/-0.15^{*}$ \\
\hline
\end{tabular}

Table I. - APP serum levels and antibody titres in women with patent and non patent P. falciparum.

All parameters are expressed in $\mathrm{g} / \mathrm{l}$ except for RBP and CRP which are expressed in $\mathrm{mg} / \mathrm{l}$.

* $\mathrm{p}=0.03$ by the Mann Whitney test.
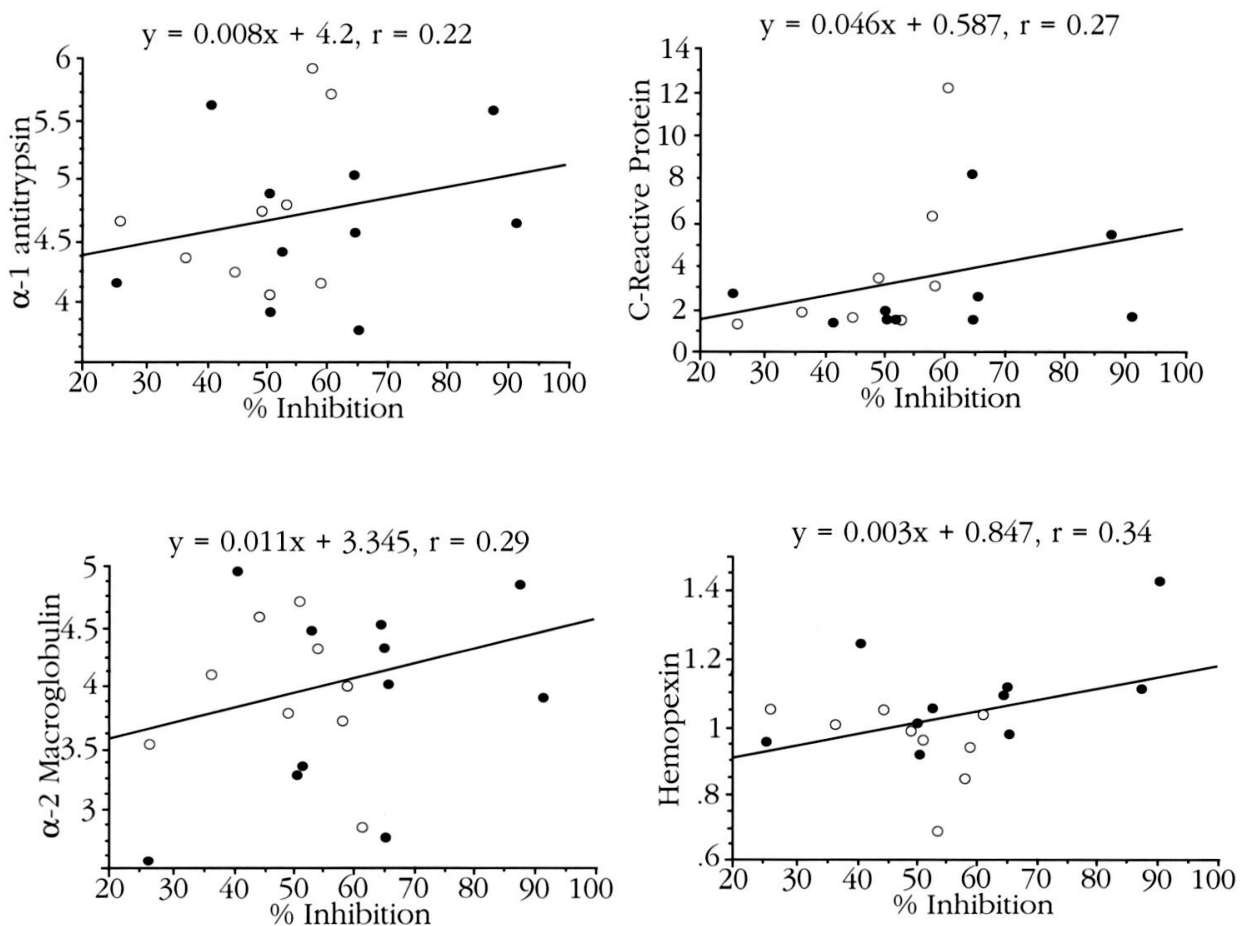

1

- Non infected

- Infected

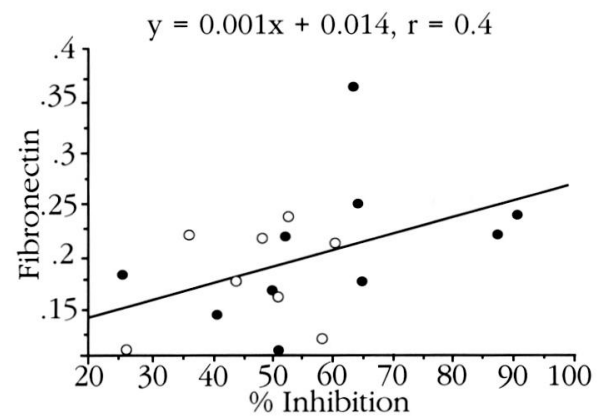

Fig. 1. - Effect of sera on intrahepatic schizogony of $P$. yoelii. Individual sera were added to hepatocyte cultures at the time of infection with $P$. yoelii sporozoites. Cultures were stopped $48 \mathrm{~h}$ after infection. Data are presented as the mean reduction in parasite numbers from triplicate counts. Statistical calculation was performed with the non-parametric Mann Whitney U test. The relationship between two variables was tested by the Pearson correlation coefficient. P values less than 0.05 were considered as significant. 


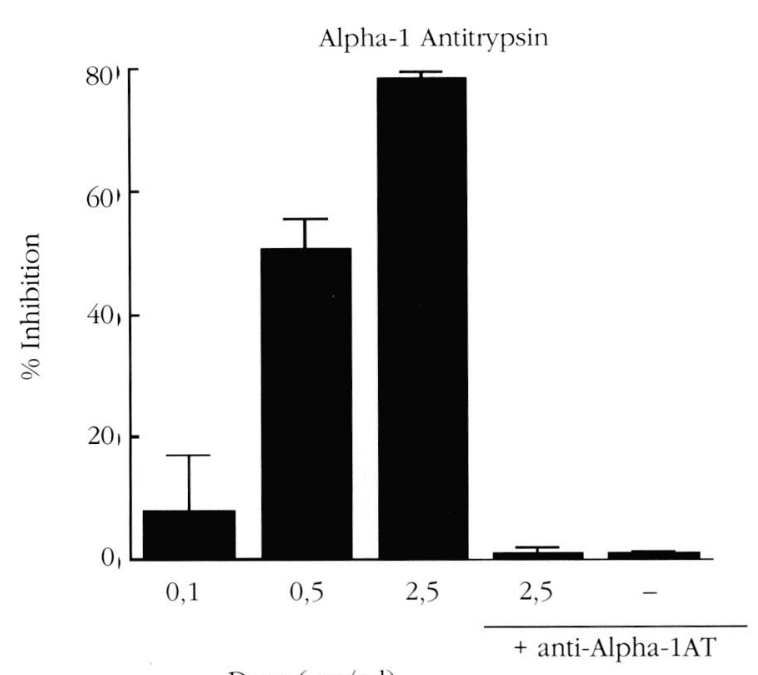

Dose $(\mathrm{mg} / \mathrm{ml})$
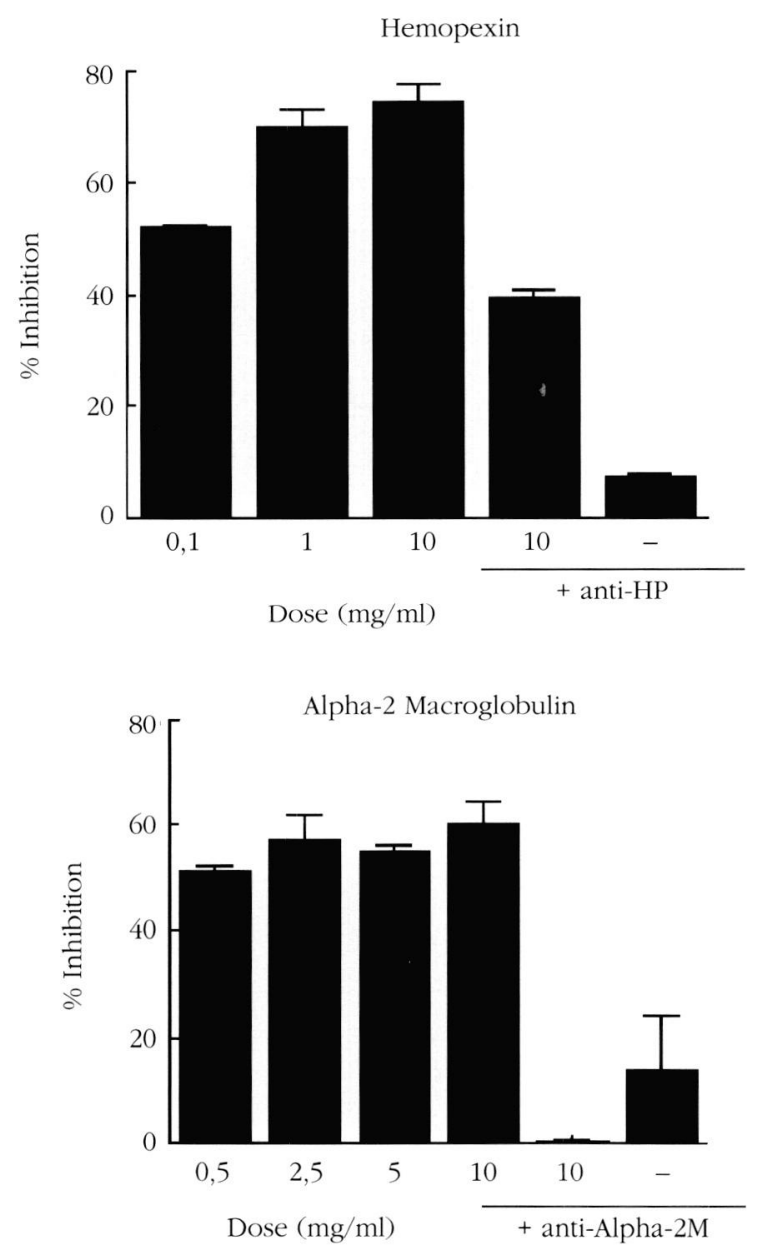

Fig. 2. - Timing of the antiparasite effect of $\alpha-1$ antitrypsin, hemopexin and $\alpha-2$ macroglobulin. Two experiments were performed : Purified proteins were added to cultures at the time of sporozoite inoculation. Antisera specific to each acute phase protein were included in some of the wells. All cultures were examined $48 \mathrm{~h}$ after infection. The number of schizonts in control wells was $94+/$ 3.5 . levels against $P$. falciparum sporozoïtes and the presence or absence of parasites.

INHIBITORY EFFECT OF SERA ON PLASMODIUM YOELII GROWTH IN HEPATIC CELL CULTURES

We analyzed the potential of plasma proteins in serum samples depleted of total immunoglobulins to inhibit the development of sporozoites in primary cultures of Balb/c mouse hepatocytes (Figure 1). A relationship was found between the capacity of these sera to inhibit parasite growth and serum levels of $\alpha$ 2 macroglobulin $(r=0.3, p=0.21), \alpha-1$ antitrypsin $(r$ $=0.38, \mathrm{p}=0.2)$ and hemopexin $(\mathrm{r}=0.35, \mathrm{p}=0.15)$.

\section{IN VITRO EFFECT OF PURIFIED PLASMA PROTEINS ON} THE HEPATIC STAGES OF PLASMODIUM YOELII

As shown on Figure 2, addition of $\alpha-1$ antitrypsin to hepatic cultures at the time of sporozoite inoculation resulted in a dose dependent inhibitory effect on both parasite invasion and postpenetration development. Comparable effects were obtained with purified hemopexin and $\alpha-2$ macroglobulin. Polyclonal sera directed against $\alpha-1$ antitrypsin, $\alpha-2$ macroglobulin and hemopexin respectively greatly reduced the inhibitory effects.

\section{DISCUSSION}

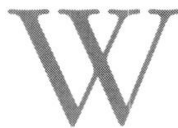
e have evidence here indicating that nonspecific factors can be involved very early in the control of malaria infection. Using sera from parasitaemic and non-parasitaemic volunteers living in a $P$. falciparum endemic area of Thailand, we have demonstrated that malaria parasite development in the hepatocyte is subject in vitro to modulation by several acute phase plasma proteins since we observed correlations between serum levels of some of the proteins and the ability of these sera, when depleted of antibodies, to inhibit the intrahepatocytic development of $P$. yoelii.

The comparison of different plasma proteins in sera from both groups revealed differences in the levels of haptoglobin, $\alpha-1$ antitrypin, $\alpha-2$ macroglobulin and hemopexin in the women with or without current infections. Correlations were found between the levels of these APPs and the inhibitory potential of sera. Furthermore, addition of purified $\alpha-1$ antitrypsin, $\alpha-2$ macroglobulin, hemopexin to $P$. yoelii hepatic phase cultures interfered with development in a dose-dependent manner; this effect was reversed with the corresponding antibodies.

The exact role played by these serum factors in pro- 
tection against malaria has still to be established concerning erythrocytic stage. Alpha - 2 macroglobulin and $\alpha-1$ antitrypsin are major protease inhibitors in serum that respectively bind irreversibly to proteolytic enzymes such as carboxyl, thiol, serine and metal proteases, and to trypsin, chymotrypsin or neutral proteases and modify their activities (James et al., 1980 ; Van Furth et al., 1983). The existence of proteolytic activity in the erythrocytic stages of Plasmodium is well described in the literature (Shrevel et al., 1990). These malaria proteases are divided in two groups, one active in an acidic environment and involved in haemoglobin degradation (Bailly et al., 1991; Dame et al., 1994; Goldberg et al., 1991; Rosenthal et al., 1989; Vander Jagt et al., 1986), the other active in schizonts and/or merozoites with a role in merozoite maturation or red blood cell invasion (Banyal et al., 1990; Braun-Breton et al., 1988; Lyon et al., 1986; Rosenthal et al., 1987). The latter could also be involved in the regulation of parasite development within the hepatocyte. Proteases are known to control a number of steps involved in the antigen processing necessary for the growth and maturation of the parasite (Hadley et al., 1989) and, more specifically, malaria proteases such as serine protease have been shown to be involved in the binding of merozoites and their entry into the red blood cell. Whether serine proteases, or more generally endopeptidases, are involved in hepatocyte invasion by sporozoites and the subsequent maturation process, require further investigation.

The in vitro effects of hemopexin on the hepatic stage remain unclear. Hemopexin is a heme-binding serum glycoprotein that participates to iron metabolism (Müller-Eberhard, 1978). We have recent evidence that iron metabolism interferes with the intrahepatic schizogony of P. yoelii (Goma et al., unpublished data).

Surprisingly, no correlation was found with CRP which is known to inhibit the penetration into and early multiplication of the sporozoite in the hepatocyte (Nussler et al., 1991c; Pied et al., 1989). This absence of correlation may be explained by the low level of CRP observed in the majority of the volunteers. This contrasts with the results of Murphy who observed an increase with infection (Murphy et al., 1972).

Although APPs are structurally and functionally a diverse group, they may limit Plasmodium infection non-specifically, in the window of time immediately after host invasion, and/or during acquired immune responses when levels of cytokines which determine the spectrum of APPs are increased (Fey et al., 1990). These results underline the role played by non speci- fic factors in protection against malaria. Moreover, understanding of their mode of action might be exploited for the development of new therapeutic strategies.

\section{ACKNOWLEDGEMENTS}

T his research was supported in part by the Commission des Communautés Européennes and by the Conseil des Universités des Réseaux d'Expression Française. We thank G.A.T. Targett and Laurent Rénia for critical discussions, and H. Matile and D. Baccam for providing P. falciparum and $P$. yoelii sporozoites.

\section{REFERENCES}

Bailly E., Savel J., Mahouhy G., \& Jaureguiberry G. Plasmodium falciparum : isolation and characterization of a $55-\mathrm{kDa}$ protease with a cathepsin D like activity from P. falciparum. Experimental Parasitology, 1991, 72, 278-284.

Banyal H.S., Abrams C.K., Slatin S.L. \& Griffiths G.AT. Cruzi-secreted protein immunologically related to the complement component C9. Evidence for membrane pore-forming at low pH. Cell, 1990, 61, 1277-1285.

Braun-Breton C., Rosenberry T.L. \& Pereira da silva L. Induction of the proteolytic activity of a membrane protein in $P$. falciparum by phosphatidyl inositol-specific phospholipase C. Nature (London), 1988, 332, 457-459.

Dame J.B, Reddy G.R., Yowell C.A., Dunn B.M., Kay J. \& BERRY C.S. Sequence, expression and modeled structure of anaspartic proteinase from the human malaria parasite Plasmodium falciparum. Molecular and Biochemical Parasitology, 1994, 64, 177-190.

FEY G. \& GAULDIE J. The acute phase response of the liver inflammation. Progress in liver. Disease, 1990, 9, 89-101.

Goldberg D., Scater A.F., Beavis R., Chart B., Cerami A. \& Henderson G. Hemoglobin degradation in the human malaria pathogen Plasmodium falciparum : a catabolic pathway initiated by a specific aspartic protease. Journal of Experimental Medecine, 1991, 173, 961-969.

Hadley T., Aikawa M. \& Miller L. Studies on invasion of rhesus erythrocytes by merozoites in the presence of protease inhibitors. Experimental Parasitology, 1983, 55, 306-311.

JAMES K. Alpha-2 macroglobulin and its possible importance in the immune system. Trends Biochemical Science, $1980,5,43-47$.

Lyon J. A., \& HANES J. D. Plasmodium falciparum antigens synthetized by schizonts and stabilized at the merozoite surface when schizonts mature in the presence of protease inhibitors. Journal of Immunology, 1986, 136, 224552. 
Mazier D., Beaudoin R.L., Mellouk S., Druilhe P., Texier B., Trosper J., Miltgen F., landau I., Paul C., Brandicourt O., Guguen-Gulllouzo C., Langlois P. \& Gentilini M. Complete development of hepatic stages of Plasmodium falciparum in vitro. Science, 1985, 227, 440-444.

Mazier D., Mellouk S., Beaudoin R.L., Texier B., Druilhe P., Hockmeyer W., Trosper D., Paul C., Charoenvit Y., Young J., Miltgen F., Chedid L, Chigot J.P., Galley B., Brandicourt O. \& Gentilini M. Effect of antibodies to recombinant and synthetic peptides on Plasmodium falciparum sporozoites in vitro. Science, 1986, 231, 156161.

Mazier D., Rénia L., Nussler A., Pied S., Marussig M., Goma J., Grillot D., Miltgen F., Drapier J.C., Corradin G., Del Guidice G. \& Grau G.E. Hepatic phase of malaria is the target of cellular mechanisms induced by the previous and the subsequent stages : a crucial role for the liver nonparenchymal cells. Immunology Letters, 1990, 25, 6572.

Mellouk S., Maheswari R.K., Rhodes-Feulllette A., Beaudoin R.L., Berbiguier N., Matile H., Miltgen F., Landau I., Pied S., Chigot J.P., Friedman R.M. \& Mazier D. Inhibitory activity of interferon-gamma and interleukin-1 on the development of Plasmodium falciparum in human hepatocyte cultures. Journal of Immunology, 1987, 139, 4192-496.

Müller-Eberhard U. In : Transport by proteins. G. Blauer and H. Sund eds, 1978, 295 pp.

Murphy, S. G., Klainer A. \& Clyde C. Characterization and pathophysiology of serum glycoprotein alterations in malaria. Journal of Clinical Investigation, 1972, 79, 55-59.

Nussler A., Pied S., Goma J., Rénia L., Miltgen F., Grau G. \& MAZIER D. TNF inhibits malaria hepatic stages in vitro via synthesis of IL-6. International Immunology, 1991a, 3, 317-324.

Nussler A., Drapier J.C., Rénia L., Pied S., Miltgen F., Gentilini M. \& Mazier D. L-Arginine-dependent destruction of intrahepatic malaria parasites in response to tumor necrosis factor and/or interleukin-6 stimulation. European Journal of Immunology, 1991b, 142, 549-553.

Nussler A., Pied S., Pontet M., Miltgen F., Rénia L., Gentilini M. \& MAzieR D. Inflammatory status and preerythrocytic stages of malaria : role of the C-reactive protein. Experimental Parasitology, 1991c, 72, 1-6.

Pied S., Nussler A., Pontet M., Miltgen F., Matile H., Lambert P.H., Gentilini M. \& Mazier D. C-reactive protein protects against pre-erythrocytic stages of malaria. Infection and Immunity, 1989, 57, 278- 282.

Pied S., Civas A., Berliot-Piccard F., Rénia L., Miltgen F., Gentilini M., Doly J., \& Mazier D. IL-6 induced by IL-1 inhibits malaria pre-erythrocytic stages but its secretion is down-regulated by the parasite. Journal of Immunology, 1992, 148, 197-201.

Pied S., Rénia L., Nussler A., Miltgen F. \& Mazier D. Inhibitory activity of interleukin-6 on malaria hepatic stages. Parasite Immunology, 1990, 13, 607-611.

Rénia L., Salone-Marussig M., Grillot D., Corradin G.P., Miltgen F., Del Giudice G. \& Mazier D. In vitro activity of
CD4+ and CD8+ T lymphocytes from mice immunized with a malaria synthetic peptide. Proceeding National Academic Science, 1991, 88, 7963-7969.

Rosenthal P. J., Kim K., McKerrow J. H. \& Leech J. Identification of three stage-specific proteinases of Plasmodium falciparum. Journal of Experimental Medecine, 1987, 166, 816-821.

Rosenthal J.P., McKerrow J.H., Rasnick D. \& Leech J.H. Plasmodium falciparum : inhibitors of lysosomal cysteine proteinases inhibit a trophozoite proteinase and block parasite development. Molecular Biochemical Parasitology, 1989, 35, 177-183.

Schofield L., Nussenzweig R.S. \& Nussenzweig V. CD $8+T$ cells and gamma interferon required for immunity to sporozoite challenge. Report of the Tenth Meeting of the Scientific Working Group on the Immunology of Malaria, 1988, 17 pp.

SCHofield L. T cell immunity to malaria sporozoites. Experimental Parasitology, 1989, 68, 357-367.

Shrével J., Deguercy A., Mayer R. \& Monsigny M. Proteases in malaria-infected red blood cells. Blood Cells, 1990, 16, 563-568.

Van Furth R., Kramps J.A., \& Diesselhof-Den Dulk M.C. Synthesis of alpha-1 antitrypsin by human monocytes. Clinical Experimental Immunology, 1983, 51, 551-557.

Vander Jagt D.L., Hunsaker H.A. \& Campos N.M. Characterisation of a hemoglobin-degrading low molecular weight protease from Plasmodium falciparum. Molecular Biochemical Parasitology ,1986, 18, 389-396.

Weiss R.W., Sedhega M., Beaudoin R.L., Miller L.H. \& GoOD M.F. CD8+ T cells (cytotoxic/suppressors) are required for protection in mice immunized with malaria sporozoites. Proceeding National Academic Science, USA, $1988,85,573-478$

Weiss W.R., Mellouk S., Houghten R.A., Sedegha M., Kumar S., Good M.F., Berzofsky J.A., Miller L.H. \& Hoffman S.L. Cytotoxic $\mathrm{T}$ cells recognize a peptide from the circumsporozoite protein on malaria-infected hepatocytes. Journal of Experimental Medecine, 1990, 171, 763-769.

Accepté le 10 mars 1995 